Article

\title{
Climate Security and Policy Options in Japan
}

\author{
Seiichiro Hasui ${ }^{1, *}$ and Hiroshi Komatsu ${ }^{2}$ \\ ${ }^{1}$ College of Humanities and Social Sciences, Ibaraki University, Japan; E-Mail: seiichiro.hasui.irps@vc.ibaraki.ac.jp \\ ${ }^{2}$ Center for Asian and Pacific Studies, Seikei University, Japan; E-Mail: hkomatsu@ejs.seikei.ac.jp \\ * Corresponding author
}

Submitted: 27 April 2021 | Accepted: 2 July 2021 | Published: 22 October 2021

\begin{abstract}
Climate security has been discussed in both academia and policy documents in the West. A key point that surfaces from these discussions is that the cooperation of non-military organizations is essential for effective responses to climate change-related threats. This overlaps considerably with debates on security in Japan, where the use of force is constitutionally restricted. Therefore, it is possible to localize the concept of climate security to the genealogy of Japan's security policy that, in the 1980s and 1990s, sought a non-traditional security strategy that did not rely solely on military power in the name of "comprehensive security," "environmental security," and "human security." In Japan, the perspective of climate security is rare. However, the introduction of a unique climate security concept into security policy enables the maintenance of national security and environmental conservation. Additionally, struggling with climate change alongside neighboring countries contributes to mutual confidence building and stability in international relations in Northeast Asia. To achieve this objective, we first show that climate security includes many kinds of security concerns by surveying previous studies and comparing Western countries' climate security policies. Second, we follow the evolution of Japan's security policy from 1980 to 2021 . Finally, we review Japanese climate security policies and propose policy options.
\end{abstract}

\section{Keywords}

climate change adaptation; climate disasters; comprehensive security; environmental security; human security; violent conflict

\section{Issue}

This article is part of the issue "Climate Change and Security" edited by Yasuko Kameyama (National Institute for Environmental Studies, Japan) and Yukari Takamura (University of Tokyo, Japan).

(C) 2021 by the authors; licensee Cogitatio (Lisbon, Portugal). This article is licensed under a Creative Commons Attribution 4.0 International License (CC BY).

\section{Introduction}

Climate security is an urgent concern in policymaking and research in the West. A key point that surfaces from the discussions is that the cooperation of non-military organizations is essential for military organizations to respond effectively to climate change-related threats. Climate security, which emphasizes non-military means, is beneficial to Japan, where the use of force is constitutionally restricted, but climate security is not yet an overarching concern (Kameyama \& Ono, 2021).

The term "climate security" refers to a line of thought that climate change impacts raise various security threats. Its signature is that these threats are linked to all areas of politics, the economy, and society and could result in violent conflict. However, the meanings of climate security are diverse and multifaceted, as many national and international actors have used this term in their own contexts. Many studies have tried to categorize them to cover the wide range of discourse (Baysal \& Karakaş, 2017; Hasui, 2011; Kameyama \& Ono, 2021; Kanie, 2007; McDonald, 2013).

To localize the concept of climate security to Japan, we contextualize it within Japanese climate and security policy. We then examine Japanese policymaking since the 1980 s and 1990 s to investigate a nontraditional security strategy that does not solely rely on military power in the name of "comprehensive 
security," "environmental security," and "human security." The introduction of a unique climate security concept into Japanese security policy enables both national security and environmental conservation. Further, regional cooperation on climate change improves international relations.

To this end, we first show that climate security includes many kinds of security by surveying previous studies and comparing the climate security policies of Western countries. Second, we follow the evolution of Japanese climate and security policy from 1980 to 2021. Finally, we review Japanese climate security policies and propose policy options.

\section{Research and Policy Trends on Climate Security}

\subsection{Research Trends}

Research on climate change and security has become prominent. This trend can be found in statistical research on "climate change and peace." Sharifi et al. (2020) confirm that articles on climate change and negative peace - that is, the absence of physical violence-on the Web of Science have surged since 2007 and 2015, when the Intergovernmental Panel on Climate Change (IPCC) Fourth Assessment Report was first published and the Sustainable Development Goals were adopted by United Nations Member States, respectively. According to the study, the treatises can be divided into four clusters: institutional mechanisms; violent conflict in Africa and the disaster-conflict nexus; migration and adaptation; and resource management and environmental security. The most predominant themes are "war (civil war)," followed by "immigration and conflict" and "risk."

Climate change poses a security threat because it can threaten human security and increase the risk of violent conflict. The logic is that climate change undermines human security by reducing access to and the quality of natural resources that are important for sustaining livelihoods. Climate change can also erode the very ability of states to provide opportunities and services to people for their livelihoods. Thus, the direct and indirect effects of climate change on human security have the potential to increase the risk of violent conflict (Barnett \& Adger, 2007). Climate change's status as a security issue is controversial, especially if rising temperatures lead to military conflict. To verify that logic, empirical studies have analyzed the relationship between climate change and the occurrence of violence, resulting in mixed findings.

Among skeptical authors, Gartzke (2012) analyzes the correlation between rising temperatures and the frequency of interstate conflicts since 1800, finding, instead, a fall in conflicts. Buhaug's (2010) study of various violent conflicts in Africa finds that climate change is an inadequate predictor of armed conflict, as it examines the relationship between drought fever and civil war. He states that civil war in Africa can be explained by general structural and contextual conditions such as ethno-political exclusion, poor national economies, and the collapse of the Cold War system. Another study has shown that precipitation deviations are not important and that political, economic, and geographic factors outweigh extreme weather in terms of the location and timing of violence events (O'Loughlin et al., 2014). Gleditsch (2012) argues that few studies have demonstrated a causal link between climate change and conflict and criticizes the recognition of climate change as a security issue, calling it a self-fulfilling prophecy that might lead to a military response.

By contrast, research supporting the link between climate change and conflict shows that temperatures much higher than normal increase the risk of violence (O'Loughlin et al., 2012). Hendrix and Salehyan (2012) highlight that variability in rainfall affects political conflicts and increases the possibility of violence in rainy years. A study of the relationships between climate change, food prices, and violence shows that unusually dry conditions are associated with an increasing frequency of conflict and that reduced precipitation has an indirect effect on conflict through its impact on food prices (Raleigh et al., 2015).

Research on climate security is not only empirical research but also discourse analysis. Critical security theory argues that security policy is not only based on objective facts but also relies on public opinion and the perceptions of policymakers and stakeholders. Proof of the causal relationship through data, experimentation, and policy discourse is important, necessitating a social constructionist approach.

McDonald (2013) argues that climate security discourse can be divided into national, human, international, and ecosystem security. He argues that ecological security is more effective in responding to climate change than climate security. Hayes and Knox-Hayes (2014) conducted a discourse analysis of securitization concerning climate change. They reveal the factors that cause policy differences between the EU and US. While the US emphasizes national security threats in climate security policy, Europe prioritizes economic benefits and a new world order. The authors note that the legitimacy of climate security policy has increased because of the response of traditional security actors to climate change. Ferguson (2019) classifies climate security resilience into four categories: strategic, neoliberal, social, and ecological. As actors who securitize each resilience, strategic resilience includes military organizations and thinktanks; neoliberal resilience comprises international organizations; social resilience includes citizens, non-governmental organizations, and researchers; and ecological resilience includes citizen researchers and the IPCC.

In addition, thinktanks have advocated climate security policies. The Center for Climate and Security recommended that the Japanese government manage comprehensive climate security risks, noting the unpreparedness to climate threats of the Japanese 
economy (Conger et al., 2019; Fetzek et al., 2019). Similarly, the Climate Security Expert Network judges the strength of climate security in Europe to be varied, recommending the appointment of a senior adviser/special envoy on climate security to the cabinet of the High Representative of the Union for Foreign Affairs and Security Policy, also known as the EU foreign minister (Brown et al., 2020).

Today, the actors and fields involved have expanded and diversified because of how climate change has evolved from an environmental issue to a security issue. Indeed, climate security now involves more diversified authority and complex governance.

\subsection{Climate Security Policies in the West}

How do Western countries recognize the threat of climate change? In this section, we investigate this recognition in terms of climate change mitigation and climate security using national reports. The Biden Administration has recommitted the US to the Paris Agreement. In January 2021, Biden issued an executive order stating that the climate crisis is central to US foreign policy and national security (The White House, 2021a). At the Leaders Summit on Climate in April, the US set a course for reducing greenhouse gas emissions by $50-52 \%$ of 2005 levels by 2030 and achieving net zero emissions for the entire economy by 2050 at the latest. In addition, the US expressed its commitment to create jobs, promote innovation, and achieve environmental justice by promoting climate change measures (The White House, 2021b). The US Department of Defense (DoD) considers climate change a threat to national security and highly recommends that the US military improve its capacities to adapt. A 2015 Pentagon report recognizes that climate change poses an immediate, existential threat. The report especially notes the interactions between conflict dynamics and climate change and states that, in 20 years, most military installations will be vulnerable to the effects of flood, drought, desertification, wildfire, and thawing permafrost (US Department of Defense [DoD], 2015, 2019). The DoD's latest report assesses exposure to climate hazards due to rising temperatures during the century. According to this report, hazards directly related to temperature changes (e.g., heat, droughts, wildfires) have significantly higher exposure than other hazards (e.g., coastal floods, energy demand, land degradation). Drought is a particularly dominant hazard not only in the continental US but also around the world (DoD, 2021).

In 2019, the UK became the first major country to legislate a target of net zero greenhouse gases by 2050 (Department for Business, Energy \& Industrial Strategy \& The Rt Hon Chris Skidmore MP, 2019). In December 2020, Prime Minister Boris Johnson announced a new plan that aims to reduce greenhouse gas emissions by at least $68 \%$ of 1990 levels by the end of the decade. He also stated that this would create and support 250,000 jobs (Department for Business, Energy \& Industrial Strategy et al., 2020). The British Ministry of Defense acknowledges that if the environment deteriorates, perhaps through extreme weather, community migration and social instability are inevitable. Acknowledging that climate change will affect agriculture, urban areas, the economy, and transportation, it highlights that the climate-induced disruption of water supplies and impact on agriculture could be used to push individuals to join terrorist or dissident groups (UK Ministry of Defence, 2018).

In 2016, Canada developed the Pan-Canadian Framework on Clean Growth and Climate Change as its first national climate plan, and it released A Healthy Environment and a Healthy Economy, Canada's strengthened climate plan, in December 2020. The plan aims to reduce pollution, create jobs, and support a healthy economy and environment and is a building block for achieving net zero emissions by 2050 (Government of Canada, 2021). The department of National Defence in Canada recognizes that climate change is complicating the global security environment. Canada, for example, points out that melting ice in the Arctic will increase security needs. The report also states that climate change affects the frequency, duration, and intensity of meteorological disasters such as floods, wildfires, and droughts; hence, Canadian defense should be able to respond quickly to disasters and contribute to search and rescue operations (Canadian Department of National Defence, 2020).

In 2015, Australia set a goal of reducing its greenhouse gas emissions by $26-28 \%$ of 2005 levels by 2030. Since 2020 , the responsibility for domestic climate policy and emission reduction has been transferred to the new Department of Industry, Science, Energy and Resources, while climate change adaptation strategies and climate science activities have been transferred to the Department of Agriculture, Water and the Environment (Australian Government's Department of Industry, Science, Energy and Resources, 2021). The Australian Department of Defence also sees climate change as a key challenge for the next 20 years. Rising sea levels and extreme weather will put pressure on defense activities and natural assets not only of Australia but also of neighboring countries along with such existing challenges as population growth and environmental destruction. Australia therefore states that it will remain a leader in responding to regional demands for humanitarian assistance and disaster relief (Australian Department of Defence, 2016).

New Zealand has stated that it will address climate change through leadership, productivity, sustainability, a climate resilient economy, and a just and inclusive society at home and abroad. By doing so, it aims to become a global leader in combating climate change. In November 2019, the Climate Change Response (Zero Carbon) Amendment Act 2019 legislated new domestic emission reduction targets through 2050 . The legislation 
stipulates that net emissions of all greenhouse gases should be reduced to zero by 2050 (New Zealand's Ministry for the Environment, 2021). A New Zealand Ministry of Defence report claims that climate change will be one of the greatest security challenges in the coming decades and that Pacific Island nations will be disproportionally affected by global warming: "intensifying impacts of climate change will continue to test community resilience and heighten security challenges across the culturally diverse Pacific region" (New Zealand's Ministry of Defence, 2018, p. 3). The perception is that climate change threatens both individual countries and entire regions, portending cultural loss. The report shows that climate change is linked to security and that weak governance exacerbates this negative influence. Conventional security overlaps and extends human and environmental security. Additionally, climate change policies operate on multiple levels of governance: nationally, regionally, and globally (New Zealand's Ministry of Defence, 2018). New Zealand also follows the progressive view that international cooperation on climate change measures further strengthens national defense.

Research and national documents on climate security have shown that the perception is common that climate change poses a variety of threats. Furthermore, responding to climate change requires activities by various actors and multidimensional governance. However, such perceptions of climate security have not yet become common in Japan. Therefore, in the next section, we investigate the cause by following the transition of Japan's security and climate change policy.

\section{Japan's Climate and Security Policy Transition}

\subsection{Comprehensive Security: 1980s}

The tone of Japan's security situation in the 1980s involved the escalation of the East-West confrontation after the Pax Americana and New Cold War era. The Japanese defense relied on the Japan-US Security Treaty because the Japanese Self-Defense Forces (JSDF) have been constitutionally restricted and taken as force used for "defensive defense." The Masayoshi Ohira cabinet saw comprehensive security as a means for expanding the concept of security in Japan.

The most structured arrangement of this security concept is the report of Prime Minister Ohira's policy study group. Based on the recognition that Japan had entered the "era of global society," this report viewed security issues as having a comprehensive character and defined security as "protecting people's lives from various threats" (Cabinet Secretariat, 1980, p. 8). The group divided the government's security efforts into three levels: (a) managing threats domestically, (b) making the international environment partially favorable in solidarity with likeminded countries, and (c) making the international environment holistically favorable to eliminate the threat. While discussing traditional military security issues such as Japan-US relations, strengthening self-defense, and China-Soviet Union relations, this study group also established the groundwork for economic security (e.g., energy and food) and introduced non-military threats (e.g., large-scale earthquakes) into the ambit of the Japanese security concept.

The 1980s was marked by emerging concerns about climate change. The 1985 meeting in Villach, hosted by the UN Environment Programme and others, appealed to the international community to tackle global warming for the first time. In Japan, the World Conference on the Changing Atmosphere in Toronto triggered the establishment of the Study Team on Global Warming Issues at the Air Quality Bureau of the Environment Agency in May 1988, and policy studies officially commenced. The first IPCC meeting in November 1988 was attended by 11 representatives from Japan, including the Environment Agency, the Ministry of Foreign Affairs (MOFA), the Ministry of Agriculture, Forestry and Fisheries, the Ministry of International Trade and Industry, and the Meteorological Agency (Environmental Agency Global Warming Problem Study Group, 1990). Accordingly, a forum for international and domestic discussions on climate change rapidly prevailed in the second half of the 1980s.

\subsection{Human and Environmental Security: 1990s}

After the Cold War, the threat of the Soviet Union diminished for Japan. Thereafter, the JSDF intensified its active operations, including dispatching the Maritime Self-Defense Force to the Persian Gulf after the 1991 Gulf War and participating in UN peacekeeping operations. Although the Japanese government maintained the JSDF as a "basic defense force" during peacetime, as advocated in the first National Defense Program Guideline (NDPG; Defense Agency, 1976, Chapter 2, Section 4), the new 1995 NDPG based on the post-Cold War era stated that "we will develop defense capabilities that can effectively respond to various situations, and... ensure appropriate elasticity...[to] respond smoothly to changes in situations" (Defense Agency, 1996, Chapter 2, Section 4). The redefinition of the Japan-US alliance led concurrently to the Japan-US Joint Declaration on Security (1996) and Guidelines for Japan-US Defense Cooperation (1997). This further solidified the Japan-US alliance. Subsequently, the military threat from China and North Korea escalated and the influence of the traditional military view on national security increased.

The House of Councilors Study Group on Foreign Affairs and Comprehensive Security (1992) compiled a report titled The Role of Japan in the 1990s-Concept of Environment and Security. It incorporated global environmental issues into comprehensive security to build an environmental security theory. The report covered a broad range of topics from pursuing environmental security to peaceful world order in the new era. It included important ideas that were later realized 
as policies, including establishing the Ministry of the Environment (MOE), revitalizing forests, improving food security, and promoting environmental official development assistance and climate science.

While discussions on environmental security emerged in Japan's political arena, for the post-Cold War international community, where developing countries faced newer, non-military existential crises, the UN Development Programme (UNDP) established human development and human security as policy agendas with the Human Development Reports of 1993 and 1994. In a subsequent report, it argued that the "concept of security has for too long been interpreted narrowly" and called for expansion (UN Development Programme [UNDP], 1994, p. 22). The UNDP's new concept of human security included economic, food, health, environmental, personal, community, and political security (UNDP, 1994). The World Commission on Environment and Development's report Our Common Future also mentioned environmental and climate security (World Commission on Environment and Development, 1987). Western countries also discussed these concepts (Dabelko \& Simmons, 1997; Dalby, 1992; Homer-Dixon, $1994,1999)$. This movement later formed the basis of climate security theory.

Instead of the environmental security concept, which was not so widely known at that time, Japan incorporated human security, which included environmental security as a component, into its foreign policy under Foreign Minister Keizo Obuchi (later prime minister) in response to the 1998 Asian financial crisis (Kurusu, 2011). The Japanese government actively engaged in human security diplomacy, including the establishment of the Commission on Human Security, cochaired by Sadako Ogata and Amartya Sen, at the 2000 Millennium Summit. The report stressed "protection" and "empowerment" by states and other actors (Commission on Human Security, 2003). Japan recognized human security as non-military security concept and chose as foreign policy to emphasize freedom from want. This movement accorded with a Japanese tradition that places greater importance on non-military security in the context of, for example, earthquakes or the environment. Japan utilized this concept as official development assistance policies for developing countries to make the international environment holistically favorable, as shown in the comprehensive security policy in the 1980s. This choice is different from that of Canada, which developed a foreign policy centered on freedom from fear, focusing on peacekeeping operations and actively participating in operations on the Balkan Peninsula. Such conceptual flexibility is key to human security (Huliaras \& Tzifakis, 2007), allowing it to be localized and incorporated into government policy.

In climate politics in Japan, the Global Environment Department was established at the Environment Agency and the Global Warming Prevention Action Plan was announced in 1990. Thus, the Japanese government's cli- mate change countermeasures were in the implementation stage. However, from the establishment of Japan's Environment Agency in 1971 to the enactment of the Basic Environment Law in 1993, more than 20 years elapsed before environmental policies were integrated into the national legal system. At the time, Japanese environmental diplomacy achieved spectacular results, such as the establishment of and contribution to the UN Environment Programme and negotiations at the IPCC and UN Framework Convention on Climate Change. Until the early 1990s, Japan's climate change diplomacy had only a fragile institutional base. However, at the third Conference of the Parties to the UN Framework Convention on Climate Change in 1997, the then largest international conference ever held in Japan, the Kyoto Protocol was successfully adopted despite internal frictions between the Ministry of International Trade and Industry and Environment Agency (Takeuchi, 1998).

\subsection{Emergency Legislation and Climate Security: 2000 s}

The North Korean launch of Taepodong in August 1998 impressed upon the Japanese people the enormous threat to their military security. The Obuchi cabinet, which adopted human security as a foreign policy, also passed an act to strengthen its military alliance with the US and, at the end of 2003, the JSDF were dispatched to Iraq. The NDPG was revised in 2004 when the government pursued security at three levels, namely, Japan's own efforts, the Japan-US alliance, and cooperation with the international community, along the same line as comprehensive security in the 1980s. Although the Japanese government stated that "the possibility of full-scale aggression against Japan is decreasing" (Defense Agency, 2004), the government aimed to expand the JSDF's capabilities and range of activities on the grounds of the high degree of uncertainty and unpredictability of security situations. In 2007, the Defense Agency became the Ministry of Defense (MOD), when the position of the JSDF's overseas activities changed from secondary to primary missions. The JSDF were deployed to Nepal, Sudan, and the waters off Somalia.

In 2001, Japanese Environment Agency was reorganized and became the MOE. In climate diplomacy, the Kyoto Protocol came into effect in 2005. Since that year, climate change has begun to be discussed seriously in the global political arena in relation to security. British Foreign Secretary, Margaret Beckett, stressed climate security in a remark she made at the 2005 Gleneagles Group of Eight Summit. She emphasized the need for climate security at the 2006 UN General Assembly as well (UN General Assembly, 2006). This was beginning of the international climate security debate.

The MOE moved swiftly to incorporate the climate security concept into its policy agenda. Discussions among policymakers began in February 2007 under the Sub-Committee on International Climate Change Strategy Global Environment Committee, Central 
Environment Council. Although the committee specified that the need for the concept had been recognized in Japan after October 2006, mentions of climate security were raised on consecutive occasions.

The possibility of the policy implementation of the climate security concept was discussed three times by the committee and resulted in the 2007 Climate Security Report (Ministry of the Environment [MOE], 2007). It defined climate security as focusing on the "fundamental elements of security-that is, who must act to protect what values from what threats, and in what manner" (MOE, 2007, p. 17). Nations must act to protect the safety and welfare of citizens from the broad threats of climate change caused by emissions of greenhouse gases in each nation's mitigation and adaptation measures and international cooperation (MOE, 2007). The report highlights that the concept of climate security in Japan was created through (a) international debates on climate security, (b) accelerating climate change, (c) the evolution of the concept of security, and (d) the concept of comprehensive security. The report also recommends the need to respond to climate change as a security issue and highlights the advantages of the climate security concept. Finally, it finalizes climate security policies based on comprehensive security and the contribution to human security as well as Japan's role with respect to climate security to promote building a low-carbon society and reducing greenhouse gases through international negotiation. The report indicates that climate change should be given central attention since it influences other security concerns. The report recommends incorporating climate security into national and international policies. However, it does not specify the positions or methods for national or foreign policies (Hasui, 2011).

Why is climate security struggling to become a major political issue in Japan? From an academic perspective, one reason is the difference in attitude toward environmental security studies between Japan and Western countries. The relationship between climate change and security has been disputed within environmental security studies since the 1990s and positive research published in the US and Europe since the 2000s. However, Japanese scholars tend to maintain a cautious position (Ochiai, 2001; Ohta, 2002; Yamada, 1999).

From a political perspective, one of the biggest obstacles is the absence of dynamism between political parties. Since World War II, the pro-US conservative Liberal Democratic Party (LDP) has often been in power. Due to this absence, Japan has almost no synergistic effect between political parties like the West. In 2009, the center-left Democratic Party of Japan (DPJ) took power from the LDP for the first time. The Yukio Hatoyama cabinet of the DPJ aimed to reduce greenhouse gases by $25 \%$ from 1990 levels by 2020, so climate change mitigation policies were also expected to progress. However, Hatoyama resigned owing to unrelated domestic issues in the next year, and the DPJ suffered some confusion in policymaking. Climate security policies were no exception, and they stalled despite a regime change.

\subsection{National Security and Proactive Strategies: 2010 s}

In March 2010, the DPJ submitted a bill named the Basic Law of Global Warming Countermeasures. However, it did not refer to climate security discourse. On the contrary, the LDP, as the opposition party at that time, submitted a bill named the Basic Law of Promoting Building a Low-Carbon Society. The bill stated that "global warming is a security issue that destabilizes the continuing existence of humankind and its prevention is a problem common to all humankind" (House of Representatives, 2010a). Another opposition party, Komeito, submitted another bill named the Basic Law of the Promotion of Climate Change Countermeasures. In its preamble, the bill stated that "climate change is recognized as a threat that destabilizes human existence. From this viewpoint of climate security, under international cooperation, the mitigation and adaptation of climate change is one of the biggest issues of humankind" (House of Representatives, 2010b). Thus, debate on climate change and security heated up in the Japanese Diet. However, the bills did not pass during the sessions in the Diet and were scrapped.

Around the same time, bills on climate security were submitted to Congress in the US, but they too were abandoned. These were the Climate Security Act of 2007, known as the Lieberman-Warner bill, and the American Clean Energy and Security Act of 2009, known as the Waxman-Markey bill. Both insisted that climate change posed serious security threats to humanity. However, as a result of the intentions of the business community and political dynamics of Congress and the Diet, neither Japan nor the US passed a law that embodies climate security.

In March 2011, the Great East Japan Earthquake forced all nuclear power plants in Japan to shut down. According to an ex-MOFA bureaucrat, Takehiro Kano, the Great Earthquake made it clear that a major review of nuclear energy policy was required. Nuclear power policy and Japan's climate change countermeasures, which had been two sides of the same coin, became difficult to manage. It also became difficult to allocate human resources to climate change policy owing to the earthquake disaster and nuclear accident, which subsequently influenced climate change negotiations (Kano, 2013). Nuclear power accounted for $11.3 \%$ of Japan's primary energy supply in 2010 (Agency for Natural Resources and Energy, 2012); it was unclear whether this could be compensated for by energy saving or renewable energy, preventing carbon emission increases (Kano, 2013). As a result, Japan did not participate in the extended Kyoto Protocol.

In 2012, the LDP regained power and Komeito joined as a coalition party. The cabinet of Shinzo Abe, which emphasized the Japan-US alliance and military capability, established the National Security Council (NSC) modeled on the US' NSC and formulated the National Security 
Strategy for the first time in Japan in 2013. In this document, the section "Challenges to Human Security" insists that "Japan needs to promote necessary measures based on the principle of human security" (National Security Council [NSC], 2013, p. 10). The "Global Economy and Its Risk" section refers to "the aggravating environmental problems arising from climate change," which entail the risk of "crunches in global supply and demand as well as temporary shortages of supply in food and water" (NSC, 2013, p. 11).

In December 2017, Japan held the meeting of the UN Security Council (UNSC) with 42 non-member states to discuss the maintenance of international peace and security. In this meeting, Secretary General António Guterres stated that "climate change has emerged as a threat multiplier" (UN Security Council [UNSC], 2017, p. 2). The representative of Japan, Koro Bessho, pointed out "the rise in complex contemporary challenges to international peace and security" (UNSC, 2017, p. 3). He stated the need to adopt a more comprehensive and integrated approach, enhance cooperation with other organs within and outside the United Nations, and reform the UN. Many states, including Japan itself, stressed the importance of the security threat of climate change. This was a major achievement of the Abe administration. Despite limited Japanese academic research, this is a notable piece of recent Japanese climate diplomacy.

These political movements indicate that in the 2010s, the Abe administration attempted to rebalance Japan's security policy toward a more traditional military policy. However, Abe maintained some aspects of comprehensive security until the end of his administration.

\subsection{Current Countermeasures on Climate Change and Security}

This section examines the trend in policy documents over the last few years. Despite the debate in the UNSC in 2017, the Japanese government recognizes climate change as an economic rather than a security issue. At the Leaders Summit on Climate in April 2021, the Japanese prime minister, Suga, stated that:

[Our effort to address climate change] will be the driving force of the long-term dynamic growth of not only Japan's economy, but also the global economy. With this vision in mind, in the fall of last year, immediately after assuming the office of Prime Minister, I declared that Japan will aim for net-zero by 2050. (Ministry of Foreign Affairs [MOFA], 2021, p. 1)

His statement shows that the Japanese government is planning to link the realization of a carbon-free society to economic growth. However, there is no vision for structuring regional order, such as cooperation with neighboring countries through climate security and multi-level governance, as advocated in New Zealand.
On the contrary, the MOE's highest priority is climate change. It is predicted that the risk of meteorological disasters will increase because of global warming, and therefore, the current problem is shifting to a climate crisis. In response to such risks, the MOE is implementing policies aimed at social change for disaster prevention. It is also seeking to support developing countries, especially through the Asia-Pacific Climate Change Adaptation Information Platform (MOE, 2020a).

The MOD, whose primary mission is military security, has not yet substantially addressed climate change countermeasures. The JSDF also seek to shift to renewable energy to the extent possible. Unrelated to climate change, the JSDF propose activities to manage disaster relief, including lifesaving, emergency recovery, and life support. Internationally, the MOD is working to strengthen humanitarian assistance and disaster relief (HA/DR) cooperation, however, primarily with South Asian and ASEAN countries. In fact, two $\mathrm{C}-130 \mathrm{Hs}$ were dispatched as international emergency relief in response to the recent fires in Australia (Ministry of Defense [MOD], 2020).

Thus, although Japan's climate change policies are diverse, they are neither based on nor integrated into the idea of climate security. However, political interest in climate security has begun to emerge. The 2020 Climate Change Impact Assessment Report (Review) states that "climate security is a relatively new perspective, and although the number of studies and surveys is limited, it is also very important for taking international climate change countermeasures, and it is necessary to enhance knowledge of it" (MOE, 2020b, p. 70). In addition, new movement can be seen in 2021. In the Leaders Summit on Climate, the minister of defense defined climate change as a "linkage risk," remarking that it creates a harsh environment, destabilizes societies, and becomes a source of conflict that causes further environmental degradation (MOD, 2021).

\section{Conclusion}

We summarize the implications from the research trends and policy documents on climate security as follows. The concept of climate security recognizes the following basic course of events. Extreme weather events caused by climate change lead to economic and social instability and violent conflict, while political conflicts and climate disasters are likely to produce refugees, resource depletion, and economic stagnation, involving the need for complex responses. Therefore, when dealing with climate-related conflicts and post-conflict peacebuilding, the influence of climate change should be accounted for.

Concerns about climate security are so diverse that climate security cannot be grasped within the framework of conventional resource management aiming to secure water, food, energy, or "traditional security," relying heavily on military power. It needs close cooperation between military and non-military organizations for 
a holistic response to climate security issues. For example, the military, an organization that can operate in harsh environments, responds to HA/DR and violent conflict, whereas international organizations and non-governmental organizations respond to economic and social issues. Together, they can mitigate the impacts of climate change, thereby allowing the affected countries to adapt. Furthermore, the effects of climate change transcend national borders; international cooperation is essential for climate security policies. We confirm that improving governance capacity is important for the realization of adaptation policies that reduce the disasters caused by climate change.

These characteristics of climate security considerably overlap with the transition of Japan's security policy. Comprehensive security presented a framework in which not only military but also non-military threats should be considered as security issues. Human security has become an international norm, shifting the subject of security from nation to human. Regarding climate security, the momentum for policymaking increased within the MOE around 2007 when the report was published. A bill was also submitted by the DPJ, the LDP, and Komeito. However, the Great East Japan Earthquake and two changes of government forced the government to alter its climate policy, which relies on the operation of nuclear power plants. After that, the Abe administration, emphasizing economic growth and a return to tradi- tional security policies, achieved the longest administration. These factors failed to turn climate security into a concrete policy. Figure 1 shows the transition of Japan's climate and security policy. Since the 1980 s, various security concepts have accumulated as layers rather than discontinuous polices. Climate security stagnated in the 2010s but could once again become central to Japan's security after the 2020 s.

Finally, we present some recommendations to the Japanese government based on the above findings. To catch up with the world trends of climate security, Japan should position climate security as a core strategy. Although the possibility that climate change may have a security impact is mentioned in the NDPG (Security Council and Cabinet, 2010, p. 3), the National Security Strategy only mentions "climate change and other environmental issues" along with social inequality and infectious diseases under "human security" in Section III-1-(5). On the contrary, "ensuring maritime security" is listed in IV-1-(4). We thus recommend that climate security be listed at the same or higher level than human or maritime security. To create an organization tasked with the management of climate security issues in an integrated manner, the MOE should also participate in the NSC.

For effective and common policies on climate security, it is essential to cooperate with neighboring countries. If cooperating countries are actively concerned

\section{- Situation: New Cold War and economic interdependence \\ - New agendas: Threats to energy, food, economy and threats of earthquakes \\ - Climate change: Organization of scientific community}

1980s: Comprehensive Security

1990s: Environmental Security and Human Security

\section{- Situation: The end of} the Cold War

- New agendas: Human beings and the environment

- Climate change: Japan's diplomacy making a solid international contribution 2000s: Seeking Climate Security

- Situation: Increased military tension in East Asia

- New agendas: Attempt to introduce climate security as policy

- Climate change: Kyoto Protocol and growing attentions to climate change impacts

\section{0s: National Security Strategy 2020s: \\ - Situation: Rise of China and the Great East Japan Earthquake \\ - New agendas: Strengthening traditional security \\ - Climate change: Measured as economic growth strategy and disaster prevention \\ Climate Security? \\ - Situation: \\ Integration of \\ resource \\ management and \\ traditional security \\ - New agendas: \\ Increasing HA/DR, \\ military and \\ non-military \\ cooperation \\ - Climate change: \\ Need for \\ international \\ cooperation in Asia \\ and worldwide}

Figure 1. Transition of Japan's climate and security policies. 
about climate change issues as security problems, this could contribute to the formation of a new international/regional order. If the Japanese government can play a leading role, as it did in the UN open debate in 2017, this will build trust at the global level. However, although efforts toward self-help and a favorable international environment are strongly stated in current climate change policy, endeavors in East Asia are weak. To overcome this weakness, it is necessary to have an organization/institution with a bird's-eye view of the risks to security caused by climate change in East Asia and Japan. The Japanese government has launched the Asia-Pacific Climate Change Adaptation Information Platform and upholds the basic measures, namely, "securing a system for collecting, organizing, analyzing, and providing information" (MOE, 2018, p. 9). If actively reinforced, these measures will contribute greatly to cooperation by standardizing policy. For this purpose, domestic policy and foreign aid linked to the improvement of governance are also required, as shown in Basic Strategy 4 and 6 of the Climate Change Adaptation Plan (MOE, 2018).

The JSDF should have operations based on climate security. This works in a similar fashion to rescue operations for typhoons, heavy rain, and peacekeeping operations. These experiences may yield good practices. However, the JSDF have little experience of collaborating with other institutions, and larger institutional issues exist. According to Basic Strategy 1 of the Climate Change Adaptation Plan, the connection between security and climate change policies should not be hindered. However, Japan does not yet have an organization that integrates all policies to monitor, identify, and respond to these issues. Emphasis on climate security leads to the recognition that existing conflict deterrence measures alone are inadequate and costly. If so, Japan would prefer addressing climate change as conflict prevention.

While Japan's military security policy has been based on the Japan-US alliance, the country previously tried to establish non-military security policies. In light of the climate crisis, it is important to discuss climate security within the scope of the MOE alongside international discourse. This argument may make it appropriate to graft climate security to Japan's New Comprehensive Security policy. Along the lines of the Comprehensive Security effort, introducing the concept of climate security into Japan's non-military security policy can promote the security of the Japanese people and conservation of territory as management threats domestically (self-help). Further, common climate security policies among neighboring countries will build confidence and improve regional stability, thus making the international environment partially favorable in solidarity with likeminded countries. Lastly, with the pillar of human security, climate security will build another pillar of Japanese diplomacy in the UN and other multilateral arenas, such as the Leaders Summit on Climate. This would make the international environment holistically favorable to elim- inating the threat. To this end, Japan must conduct climate diplomacy motivated by the security of each nation. The remaining academic challenge is to analyze the similarities and differences between the climate security policies of neighboring countries and Japan. Revealing the similarities and differences would help make as many nations as possible understand the concept and benefits of climate security and standardize climate security policies.

\section{Acknowledgments}

This research was performed by the Environment Research and Technology Development Fund (JPMEERF20182001) of the Environmental Restoration and Conservation Agency of Japan.

\section{Conflict of Interests}

The authors declare no conflict of interests.

\section{References}

Agency for Natural Resources and Energy. (2012). Eneguri hakusho [Energy white paper]. https://www. enecho.meti.go.jp/about/whitepaper/2012pdf/ index.html

Australian Department of Defence. (2016). Environmental strategy 2016-2036. https://www.defence. gov.au/estatemanagement/governance/policy/ environment/Policy/EnvironmentStrategy2016.PDF

Australian Government's Department of Industry, Science, Energy and Resources. (2021). Australia's climate change strategies. https://www.industry.gov. au/policies-and-initiatives/australias-climatechange-strategies

Barnett, J., \& Adger, W. N. (2007). Climate change, human security and violent conflict. Political Geography, 26, 639-655.

Baysal, B., \& Karakaş, U. (2017). Climate change and security: Different perceptions, different approaches. Uluslararası iliş̧kiler, 14(54), 21-44.

Brown, O., More, A. L., \& Raasteen, J. (2020). Europe and climate security: Is Europe delivering on its rhetoric? The Climate Security Expert Network.

Buhaug, H. (2010). Climate not to blame for African civil wars. Proceedings of the National Academy of Sciences of the United States of America, 107(38), 16477-16482.

Cabinet Secretariat. (1980). Sogo anzenhosho senryakuOhira sori no seisaku kenkyukai hokokusho 5 [Comprehensive security strategy-Prime minister Ohira's policy study group report 5]. Printing Bureau, Ministry of Finance.

Canadian Department of National Defence. (2020). Defence energy and environment strategy: Harnessing energy efficiency and sustainabilityDefence and the road to the future, 2020-2023. 
https://publications.gc.ca/site/eng/9.890715/ publication.html

Commission on Human Security. (2003). Human security now. Communications Development Incorporated.

Conger, J., Fetzek, S., \& Fleishman, R. (2019). Climate change lessons from the US military: What Japanese industry can learn from another global enterprise (Japan Series Report 2). The Center for the Climate and Security.

Dabelko, G., \& Simmons, G. (1997). Environment and security: Core ideas and US government initiatives. SAIS Review, 17(1), 127-146.

Dalby, S. (1992). Security, modernity, ecology: The dilemmas of post-Cold War security discourse. Alternatives: Global, Local, Political, 17(1), 95-134.

Defense Agency. (1976). Boei hakusho [Defense white paper]. Printing Bureau, Ministry of Finance.

Defense Agency. (1996). Boei hakusho [Defense white paper]. Printing Bureau, Ministry of Finance.

Defense Agency. (2004). Boei hakusho [Defense white paper]. http://www.clearing.mod.go.jp/hakusho_ data/2004/2004/index.html

Department for Business, Energy \& Industrial Strategy, \& The Rt Hon Chris Skidmore MP. (2019, June 27). UK becomes first major economy to pass net zero emissions law. GOV.UK. https://www.gov.uk/ government/news/uk-becomes-first-majoreconomy-to-pass-net-zero-emissions-law

Department for Business, Energy \& Industrial Strategy, Prime Minister's Office, 10 Downing Street, The Rt Hon Alok Sharma MP, \& The Rt Hon Boris Johnson MP. (2020, December 3). UK sets ambitious new climate target ahead of UN summit [Press release]. https://www.gov.uk/government/news/uk-setsambitious-new-climate-target-ahead-of-un-summit

Environmental Agency Global Warming Problem Study Group. (1990). Chikyu ondanka o fusegu [Preventing global warming]. Nippon Hoso Shuppan Kyokai.

Ferguson, P. (2019). Discourses of resilience in the climate security debate. Global Environmental Politics, 19(2), 104-126.

Fetzek, S., Fleishman, R., \& Conger, J. (2019). Japanese industry in an unstable climate: Reducing exposure to the security implications of climate change (Japan Series Report 1). The Center for the Climate and Security.

Gartzke, E. (2012). Could climate change precipitate peace? Journal of Peace Research, 49(1), 177-192.

Gleditsch, N. P. (2012). Whither the weather? Climate change and conflict. Journal of Peace Research, 49(1), 3-9.

Government of Canada. (2021). What's in Canada's climate plan. https://www.canada.ca/en/services/ environment/weather/climatechange/climate-plan/ climate-plan-overview.html

Hasui, S. (2011). Climate security and its implications for integrating paradigms of development and security. In S. Iai, S. Takamitsu, \& S. Ikkatai (Eds.), Achieving global sustainability: Policy recommendations (pp. 279-321). United Nations University Press.

Hayes, J., \& Knox-Hayes, J. (2014). Security in climate change discourse: Analyzing the divergence between US and EU approaches to policy. Global Environmental Politics, 14(2), 82-101.

Hendrix, C. S., \& Salehyan, I. (2012). Climate change, rainfall, and social conflict in Africa. Journal of Peace Research, 49(1), 35-50.

Homer-Dixon, T. F. (1994). Environmental scarcities and violent conflict: Evidence from cases. International Security, 19(1), 5-40.

Homer-Dixon, T. F. (1999). Environment, scarcity, and violence. Princeton University Press.

House of Representatives. (2010a). Teitanso shakai zukuri suishin kihon hoan [Basic bill of promoting building a low-carbon society]. https://www.shugiin. go.jp/internet/itdb_gian.nsf/html/gian/honbun/ houan/g17405007.htm

House of Representatives. (2010b). Kikohendo taisaku suishin kihon hoan [Basic bill of the promotion of climate change countermeasures]. https://www. shugiin.go.jp/internet/itdb_gian.nsf/html/gian/ honbun/houan/g17405015.htm

Huliaras, A., \& Tzifakis, N. (2007). Contextual approaches to human security: Canada and Japan in the Balkans. International Journal, 62(3), 559-576.

Kameyama, Y., \& Ono, K. (2021). The development of climate security discourse in Japan. Sustainable Science, 16(1), 271-281.

Kanie, N. (2007). Kiko anzenhosho o meguru kokusai chitsujo Keisei e: Haiporitikkusuka suru kankyo seiji no shinso [Toward the formation of an international order on climate security: The truth of highly politicizing environmental politics]. Gendai Shiso, 35(12), 210-221.

Kano, T. (2013). Kankyo gaiko-kiko hendo kosho to gurobaru gabanansu [Environmental diplomacyClimate change negotiations and global governance]. Shizansha.

Kurusu, K. (2011). Gendankai no "ningen no anzenhosho" ["Human security" at the current stage]. International Affairs, 603, 5-14.

McDonald, M. (2013). Discourses of climate security. Political Geography, 33, 42-51.

Ministry of Defense. (2020). Defense of Japan (Annual white paper). https://www.mod.go.jp/en/publ/w_ paper/index.html

Ministry of Defense. (2021). "Kiko samitto kiko anzenhosho sessyon" Kishi boei daijin supichi genko [Remarks at climate security session during Leaders Summit on Climate by minister of defense of Japan]. https://www.mod.go.jp/j/press/news/2021/ 04/23b.pdf

Ministry of Foreign Affairs. (2021). Leaders Summit on Climate remarks by H.E. Mr. Suga Yoshihide, Prime Minister of Japan. https://www.mofa.go.jp/mofaj/files/ 100181623.pdf 
Ministry of the Environment. (2007). Report on climate security. https://www.env.go.jp/en/earth/cc/CS.pdf

Ministry of the Environment. (2018). Kiko hendo tekio keikaku [Climate change adaptation plan]. https:// www.env.go.jp/earth/tekiou/tekioukeikaku.pdf

Ministry of the Environment. (2020a). Reiwa 2 nenban kankyo junkangata shakai seibutsu tayosei hakusho [Annual report on the environment: The sound material-cycle society and biodiversity in Japan 2020]. https://www.env.go.jp/policy/hakusyo/r02/ pdf.html

Ministry of the Environment. (2020b). Kiko hendo eikyo hyoka hokokusho (sosetsu) [Climate change impact assessment report (review)]. https://www.env.go. jp/press/files/jp/115261.pdf

National Security Council. (2013). National security strategy. http://japan.kantei.go.jp/96_abe/documents/ 2013/_icsFiles/afieldfile/2013/12/17/NSS.pdf

New Zealand's Ministry for the Environment. (2021). About New Zealand's climate change programme. https://environment.govt.nz/what-government-isdoing/areas-of-work/climate-change/about-newzealands-climate-change-programme

New Zealand's Ministry of Defence. (2018). The climate crisis: Defence readiness and responsibilities. https://www.defence.govt.nz/assets/Uploads/ 66cfc96a20/Climate-Change-and-Security-2018.pdf

O'Loughlin, J., Linke, A. M., \& Witmer, F. D. W. (2014). Effects of temperature and precipitation variability on the risk of violence in sub-Saharan Africa, 1980-2012. Proceedings of the National Academy of Sciences of the United States of America, 111(47), 16712-16717.

O'Loughlin, J., Witmer, F. D. W., Linke, A. M., Laing, A., Gettelman, A., \& Dudhia, J. (2012). Climate variability and conflict risk in East Africa, 1990-2009. Proceedings of the National Academy of Sciences of the United States of America, 109(45), 18344-18349.

Ochiai, K. (2001). Kankyo anzenhosho-kakusan suru gainen [Environmental security-Diffusion of the concept]. In T. Akaneya \& K. Ochiai (Eds.), Atarashii anzenhoshoron no shiza [Perspectives on new security studies] (pp. 150-182). Akishobo.

Ohta, H. (2002). Kankyo mondai o meguru kikikanri to yobo [Crisis management and prevention for environmental problems]. In H. Kimura (Ed.), Kokusai kikigaku [International crisis studies] (pp. 324-345). Sekaishisosha.

Raleigh, C., Hyun, J. C., \& Kniveton, D. (2015). The devil is in the details: An investigation of the relationships between conflict, food price and climate across Africa. Global Environmental Change, 32, 187-199.

Security Council and Cabinet. (2010). National defense program guidelines for FY 2011 and beyond. https:// warp.da.ndl.go.jp/info:ndljp/pid/11591426/ www.mod.go.jp/e/d_act/d_policy/pdf/guidelines FY2011.pdf

Sharifi, A., Simangan, D., \& Kaneko, S. (2020). Three decades of research on climate change and peace: A bibliometrics analysis. Sustainability Science, 16, 1079-1065. https://doi.org/10.1007/s11625-02000853-3

Takeuchi, K. (1998). Chikyu ondanka no seijigaku [Politics of global warming]. Asahi Shimbunsha.

The House of Councilors Study Group on Foreign Affairs and Comprehensive Security. (1992). 90 nendai no nihon no yakuwari-kankyo to anzenhosho no arikata [The role of Japan in the 1990s-Concept of environment and security]. House of Councilors First Special Investigation Office.

The White House. (2021a). Executive order on tackling the climate crisis at home and abroad. https:// www.whitehouse.gov/briefing-room/presidentialactions/2021/01/27/executive-order-on-tacklingthe-climate-crisis-at-home-and-abroad

The White House. (2021b). Fact sheet: President Biden sets 2030 greenhouse gas pollution reduction target aimed at creating good-paying union jobs and securing U.S. leadership on clean energy technologies. https://www.whitehouse.gov/briefing-room/ statements-releases/2021/04/22/fact-sheetpresident-biden-sets-2030-greenhouse-gaspollution-reduction-target-aimed-at-creating-goodpaying-union-jobs-and-securing-u-s-leadership-onclean-energy-technologies

UK Ministry of Defence. (2018). Global strategic trends: The future starts today. https://www.gov.uk/ government/publications/global-strategic-trends

UN Development Programme. (1994). Human development report 1994. Oxford University Press.

UN General Assembly. (2006). Sixty-first session 16th plenary meeting (A/61/PV.16). https://undocs.org/en/ A/61/PV.16

UN Security Council. (2017). Seventy-second year 8144th meeting (S/PV.8144). https://www.security councilreport.org/un-documents/document/ spv8144.php

US Department of Defense. (2015). National security implications of climate-related risks and a changing climate. https://obamawhitehouse.archives.gov/ sites/default/files/docs/National_Security_ Implications_of_Changing_Climate_Final_ 051915.pdf

US Department of Defense. (2019). Report on effects of a changing climate to the Department of Defense. https://media.defense.gov/2019/Jan/29/2002084 200/-1/-1/1/CLIMATE-CHANGE-REPORT-2019.PDF

US Department of Defense. (2021). DoD installation exposure to climate change at home and abroad. https://media.defense.gov/2021/Apr/20/ 2002624613/-1/-1/1/DOD-INSTALLATIONEXPOSURE-TO-CLIMATE-CHANGE-AT-HOME-ANDABROAD.PDF

World Commission on Environment and Development. (1987). Report of the World Commission on Environment and Development: Our common future. 
Yamada, T. (1999). Kankyo anzenhosho to kokusai tochi [Environmental security and international governance]. In M. Naya \& I. Takeda (Eds.), Shin anzen- hosho no kozu [Construct of new security studies] (pp. 115-148). Keisoshobo.

\section{About the Authors}

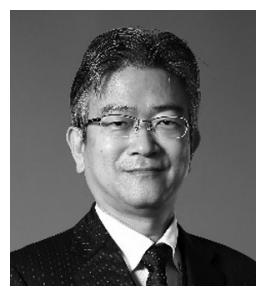

Seiichiro Hasui is a professor at the College of Humanities and Social Sciences and director of the Global and Local Environment Co-creation Institute (GLEC), Ibaraki University. He acquired his MA of International Studies from Meiji Gakuin University's Graduate School of International Studies. He completed the Doctoral Program without degree in the Graduate School of Social Sciences in University of Tsukuba. His fields of expertise include international relations, environmental politics, and peace studies. His works in climate security studies include Climate Security and Its Implications for Integrating Paradigms of Development and Security (2011) by UNU Press.

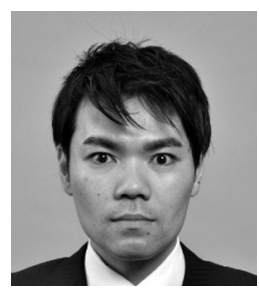

Hiroshi Komatsu is a chief research fellow at the Center for Asian and Pacific Studies, Seikei University. He earned his MA and PhD from Waseda University's Graduate School of Social Sciences. He specializes in international relations in East Asia. His primary publications include For and Against Reversion of Okinawa to Japan (2015), Revisiting Japan's Security from Okinawa (co-authored, 2015) and Multi-Layered Sub-Regions and New Regional Architecture in East Asia (co-authored, 2020). 